\title{
Daniel A. Bell: The China Model: Political Meritocracy and the Limits of Democracy
}

(Princeton University Press, 2015), 336p., \$29.95 Hardcover

\author{
Bingdao Zheng ${ }^{1}$
}

Received: 13 December 2015/ Accepted: 4 January 2016/Published online: 24 February 2016

(C) Fudan University and Springer Science+Business Media Singapore 2016

In this impressive book, Daniel A. Bell brings to our attention one of the most fundamental questions in political philosophy and in contemporary political science, that is, how to structure a political system which selects and promotes political leaders with "superior ability and virtue", and capability of "making intelligent, morally informed political judgments" (p. 2). The arguments presented in this wellwritten book, with no doubt, are both theoretically and practically significant, as the author quotes American sociologist Daniel Bell (1919-2011), "The quality of life in any society is determined, in considerable measure, by the quality of leadership. A society that does not have its best men at the head of its leading institutions is a sociological and moral absurdity" (p. 2).

This book provides a comprehensive observation and intelligent understanding of the political operation processes in various political systems such as United States, Singapore, China, as well as Hong Kong and Taiwan among others, using comparative perspective. The study establishes a quite ambitious goal of reconciling political meritocracy and democracy, with an attempt to theorize a political model that guarantees both qualified and legitimate political leadership, and has achieved this goal convincingly. Starting from pointing out some major flaws of the takenfor-granted one person, one vote system, the book makes a point that political meritocracy at least could serve as a practical alternative. This is followed by an insightful discussion on the criteria for selecting political leaders, to maximize the advantages of the meritocratic political system. The author then examines the key challenges which can be faced while implementing such a meritocracy model to minimize its disadvantages. After depicting the relative pros and cons of three

Bingdao Zheng

bingdaozheng@gmail.com

1 Fudan University, Shanghai, China 
possible models of "democratic meritocracy" (p. 151), the author prescribes the vertical model, that is, "democracy at the bottom, experimentation in the middle, and meritocracy at the top" as the optimized solution for China (p. 178).

The author in Chapter 1, entitled "Is Democracy the Least Bad Political System?", not only highlights some of the flaws associated with democracy but also sharply argues that these flaws can even be remedied through means of political meritocracy. The most obvious flaw discussed in the chapter is "the tyranny of the majority" (p. 21), that is, the majorities of voters do not always act rationally in decision making due to their limited political knowledge and biased cognition. Selfinterested majorities even abuse their voting power to oppress minority groups and unpopular individuals. Singapore-style political meritocracy, which to large extent constrains voters' power and examines voters' competence in elections, is argued as a practical way to avoid "the tyranny of the majority". The author refers to another flaw as "the tyranny of the minority" (p. 36), as economically privileged groups may intervene in the political process disproportionately, jeopardizing the policy progress for common interests. China's political model of curbing capitalists and promoting social interactions is considered to be a practicable cure. The third flaw is summarized as "the tyranny of the voting community" (p. 46), meaning that the political power is exclusively shared by the voters, however, the interests of anybody outside the voting community are neglected or sacrificed, such as those of foreigners or future generations. The author argues that the political meritocracy in Singapore that uses a president's veto authority to prevent the interests of non-voters from being systematically discriminated is a practicable alternative. Another flaw being discussed is "the tyranny of competitive individualists (p. 54)". The open ultra-competition for ruling power among multiple political parties normally exacerbates social segregation and conflicts, and therefore results into the disruption of social harmony. Although conflict is inevitable in any social context, China, under a political system with no competitive party politics, is perceived as more harmonious than some democratic countries, the author argues.

Chapter 2 enumerates three qualities that the author considers as most important in selecting and promoting political leaders: intellectual ability, social skills, and virtue. Intellectual ability plays an important role in contemporary politics as political decision making in today's world involves interdisciplinary knowledge and global insight. The imperial examination system started as early as Han dynasty, as its relative fairness opened a social upward mobility channel for the bottom of the society, it managed to serve as effective initiatives of recruiting officials with intellectual superiority. Besides first-class intellect, sophisticated social skills might be even more crucial in determining political success. The author suggests that more senior and female officials may improve the social skills of our political leadership. Virtue is the key for political leaders with advanced intellectual and social skills to pursue the good of the people rather than immoral purposes of self-interests. The author prefers peer-review system over the examination system to select officials with virtue, as "moral character is best assessed via close acquaintance and careful observation over prolonged periods in different settings" (p. 106). Throughout the chapter, the author reminds us to bear in mind that the social context plays a key role in deciding which qualities matter the most, and the author emphasizes the 
importance of these above-mentioned qualities in the context of "large, peaceful, and modernizing meritocratic states (pp. 107-108)".

The study by no means argues that political meritocracy is perfect. In Chapter 3, the author discusses three key flaws of political meritocracy and proposes some possibilities to cope with these difficulties. The most notable problem is corruption. Rulers chosen on the basis of their own meritocracy rather than voters' preference are observed to be more likely to abuse their power, although democracy is not insusceptible to corruption, either. However, specific institutions such as independent supervisory power, high salaries and compensations that keep pace with the earnings in the private sector, are argued to be helpful in containing corruption. Ossification of political hierarchies is another problem. Meritocratically selected political leaders could "become arrogant and detached from the rest of the society", and "lose sympathy with the people they govern" (p. 127). The vigor of political meritocracy calls for the improvement of representation of marginal social groups within the ruling power, as well as an open-minded multi-dimensional definition of merit that welcomes differentiated talents into leadership. The most difficult challenge is probably that of attaining legitimacy which can be tackled, as the author suggests, by improving political participation.

Chapter 4 proposes three possible models of democratic meritocracy, and discusses the relative pros and cons of each model. The first model aims to establish a plural voting scheme that allocates extra votes to certain groups of citizens who are believed to be more capable of voting in a sensible manner (pp. 154-157). The second model, named as horizontal model, attempts to reconcile meritocracy and democracy at the central level of political institutions. Similar to Sun Yat-sen's proposal of a five-branch constitution (pp. 157-159), and Jiang Qing's proposal of three houses of parliament (pp. 162-165), horizontal model requires that the leadership based on one person, one vote and the leadership based on meritocratic selection, coexist at the central level of government. These two models could be considered as author's efforts to theoretically reconcile political meritocracy that values qualification with democracy that promotes legitimacy. However, the author admits that the first model is not politically realistic as it is not as simple to implement as it appears. Moreover, the author implies that the horizontal model may not be consolidated as the meritocratic leaders will possibly be marginalized by democratic leaders, not to mention such model is not realistic either, even in political cultures that strongly favor meritocracy. What the author actually advocates is the vertical model that combines meritocracy at the central level and democracy at the local level. This vertical model, with systematic experimentation in between the top and the bottom of political hierarchy, sketches out a general picture of the so-called China Model, the title and the core of this book.

Overall, this book is a must-read scholarly account of China's political development with stimulating questions, powerful analysis as well as theoretically relevant arguments. The discussion of political elite-recruiting system impressively spans thousands of years, from ages of empires to nowadays, and a number of countries and regions including United States, China, Singapore, Hong Kong and Taiwan among others. One has to admire the comparative perspective the author puts in various historical periods and social contexts, which I think with no doubt 
benefits from the author's living experiences in and long-time observations of various political systems. The author's efforts should be appreciated, on exploiting tremendous materials ranging from social sciences, to philosophy and history (in English, Chinese, and French) to support his arguments, as he mentions in "a note on method" (p. 11).

Despite the obvious strengths of its arguments, the book could be improved in a couple of ways. First, whether Chinese political system represents a typical "political meritocracy" model is still an open question in need of further theoretical thinking and empirical exploration. The existing literature remains largely inconclusive, about based on which CCP selects its political leaders, meritocracy or patronage or both (Bo 1996; Chen et al. 2005; Jia et al. 2015; Li and Zhou 2005; Shih et al. 2012). Second, it is assumed in the book that "political meritocracy" contributes to the spectacular growth of the Chinese economy in the past few decades, however, the relationship between political selection in China and the developmental consequences is far from being well established. An emerging literature has shown the possible economic and social costs of the closed bureaucratic system in China, such as corruption, unsustainable economic development, and the unsatisfactory public goods provision, due to the fact that Chinese political leaders are immune to the reelection pressure and are only accountable to those who determine their promotion (Chen and Kung 2015; Jia 2012). But nevertheless, the book is a solid addition to the discussion on political selection system. One may disagree with author's conclusions, however, one should agree that the book sets a good precedent for other works for an open-minded discussion on democracy and its possible alternatives.

\section{References}

Bo, Zhiyue. 1996. Economic performance and political mobility: Chinese provincial leaders. Journal of Contemporary China 5(12): 135-154.

Chen, Ye, Hongbin Li, and Li-An Zhou. 2005. Relative performance evaluation and the turnover of provincial leaders in China. Economics Letters 88: 421-425.

Chen, Ting and Kung, James Kai-sing. 2015. Do Land revenue windfalls create a political resource curse? Evidence from China (Working paper).

Jia, Ruixue. 2012. Pollution for promotion (Working paper).

Jia, Ruixue, Masayuki Kudamatsu, and David Seim. 2015. Political selection in China: complementary roles of connections and performance. Journal of the European Economic Association 13: 631-668.

Li, Hongbin, and Li-An Zhou. 2005. Political turnover and economic performance: the incentive role of personnel control in China. Journal of Public Economics 89(9-10): 1743-1762.

Shih, Victor, Christoper Adolph, and Mingxing Liu. 2012. Getting ahead in the communist party: explaining the advancement of Central Committee Members in China. American Political Science Review 106: 166-187.

Bingdao Zheng is an Assistant Professor of Public Administration at Fudan University. She received her $\mathrm{PhD}$ in Social Science from the Hong Kong University of Science and Techonology in 2013. Her primary research interests are in public economics, political economics and social policy analysis. 